\title{
Agelasines B, D and antimicrobial extract of a marine sponge Agelas sp. from Tahuna Bay, Sangihe Islands, Indonesia
}

\author{
WALTER BALANSA ${ }^{1, \bullet}$, STEVY IMELDA M. WODI ${ }^{1}$, FRETS J. RIEUWPASSA ${ }^{1}$, FRANS G. IJONG ${ }^{1,2, \bullet \bullet}$ \\ ${ }^{1}$ Department of Fisheries and Marine Science, Politeknik Negeri Nusa Utara. Jl. Kesehatan No. 1, Tahuna 95821, North Sulawesi, Indonesia. \\ Tel.: +62-432-24745, •email: walterbalansa1@ gmail.com \\ ${ }^{2}$ Faculty of Fisheries and Marine Science, Universitas Sam Ratulangi. Jl. Kampus Bahu, Manado 95115, North Sulawesi, Indonesia.

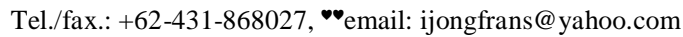

Manuscript received: 22 October 2019. Revision accepted: 22 January 2020.

\begin{abstract}
Balansa W, Wodi SIM, Rieuwpassa FJ, Ijong FG. 2020. Agelasines B, D and antimicrobial extract of Agelas sp. from Tahuna Bay, Sangihe Islands, Indonesia. Biodiversitas 21: 699-706. The alarming growth of antibiotic-resistant bacteria necessitates the discovery of new antibiotics including those for combating life-threatening ESKAPE (Enterococcus faecium, Staphylococcus aureus, Klebsiella pneumoniae, Acinetobacter baumannii, Pseudomonas aeruginosa and Enterobacter sp) and fish pathogenic bacteria. This study aimed to identify antimicrobial compounds from an extract of a marine sponge collected from Enepahembang coral reef, Sangihe Islands, North Sulawesi, Indonesia. The sponge was identified by DNA barcoding as Agelas sp. and its extract was evaluated against three ESKAPE bacteria (S. aureus, K. pneumoniae, and A. baumannii) and three fish pathogenic bacteria (A. hydrophila, Edwardsiella tarda and Vibrio parahaemolyticus), using the standard disk diffusion method. It showed moderate to strong antimicrobial activity against $S$. aureus $(25.3 \mathrm{~mm})$, K. pneumoniae $(15.5 \mathrm{~mm})$, A. baumannii $(20.2 \mathrm{~mm})$, A. hydrophila $(20.5 \mathrm{~mm})$, E. tarda $(22.4 \mathrm{~mm})$ and A. salmonicida $(21.2 \mathrm{~mm})$. The extract was isolated by chromatographic techniques (column chromatography, flash chromatography, and high-performance liquid chromatography). The structures and relative stereochemistry of the two compounds were elucidated by HRESIMS, 1D and 2D NMR data analysis as well as by comparison with reported values. Unfortunately, limited amount of the pure compounds prevented us from further evaluating their antimicrobial activity against the test bacteria. Nevertheless, the crude extract's strong antimicrobial activity, especially against the test Gram-negative bacteria, suggests the importance of this finding in light of the recent antimicrobial drug scarcity but rapid antimicrobial resistance and the emerging paradigm of antimicrobial drug modification, redirection and/or repurposing for discovering new antibiotics particularly against the life-threatening Gram-negative bacteria.
\end{abstract}

Keywords: Aeromonas hydrophila, Agelas sp., Edwardsiella tarda, Enepahembang, ESKAPE bacteria, Sangihe Islands

Abbreviations: ESKAPE: Enterococcus faecium, Staphylococcus aureus, Klebsiella pneumoniae, Acinetobacter baumannii, Pseudomonas aeruginosa, and Enterobacter sp.

\section{INTRODUCTION}

The ESKAPE bacteria are the major cause of lifethreatening nosocomial infections and are highly efficient in becoming resistant to various antimicrobial agents (Navidinia 2016). Because of their tremendous clinic and economic impacts, contributing to high mortality and health care costs (Founou et al. 2017), the World Health Organization (WHO) has listed the ESKAPE pathogens in the 12 bacteria with the most urgent need of antibiotics (Tacconelli et al. 2018). Of these, Acinetobacter baumannii, Pseudomonas aeruginosa, Klebsiella pneumoniae, Enterobacter spp and Enterococcus faecium (VRE) were classified as critical priority and $S$. aureus (MRSA and VRSA) as high priority group (WHO 2017). Similarly, there is an alarming increase in resistance of fish pathogens such as Aeromonas hydrophila, Edwardsiella tarda and Aeromonas salmonicida against the commercial antibiotics, which were recently reported to be partially effective against the fish pathogens (Miller and Harbottle 2018). Moreover, the ability of fish pathogens such as Aeromonas spp., Edwardsiella spp. and Vibrio spp. to transfer antibiotic-resistant genes to other fish pathogens exacerbates the current antibiotic resistance crisis (Miller and Harbottle 2018). Together, these facts strongly suggest a desperate need for new antibiotics to combat these deadly infectious bacteria (Tommasi et al. 2015).

In our ongoing investigation of new antibiotic drug leads from sponges of Sangihe Islands, North Sulawesi Indonesia (Balansa et al. 2017, 2019; Azhari et al. 2018), we noticed that the crude extract of a sponge collected in Enepahembang East Tahuna showed a strong antibacterial activity against three ESKAPE bacteria ( $S$. aureus, $A$. baumannii and $K$. pneumoniae) and three fish pathogenic bacteria (A. hydrophila, $V$. parahaemolyticus, and $E$. $\operatorname{tarda}$ ). This encouraged us to further identify the sponge species and investigate its active component, leading to the discovery of agelasines B and D from an Agelas sp. Over the years, agelasines have been reported to exhibit a broad range of bioactivities including antifungal against Cryptococcus neoformans, antileishmanial against Leishmania donovani and antibacterial against S. aureus and methicillin S. aureus (Yang et al. 2012), antiprotozoal against Leishmania infantum and Trypanosoma cruzi (Vik 
et al. 2009), antimalarial against Plasmodium falciparum (Appenzeller et al. 2008), antifungal against Candida albicans, antimicrobials against Staphylococcus aureus, Bacillus subtilis (Capon and Faulkner 1984), Micrococcus luteus (Vik et al. 2006), antimycobacterial against both dormant and active mycobacterium (Arai et al. 2014) and an inhibitor of $\mathrm{Na}^{+}$and $\mathrm{K}^{+}$ATPase (Nakamura et al. 1984). In particular, both agelasines $\mathrm{B}$ and $\mathrm{D}$ were reported to have anticancer against PC9, A549, HepG2, MCF-7, and U937 cancer cell lines (Hong et al., 2017) and a potent antimicrobial activity against $S$. aureus (Vik et al. 2006). To date, however, almost nothing is known about antimicrobial potential of agelasines against both Gramnegative ESKAPE (A. baumanii and $K$. pneumoniae) and fish pathogenic ( $V$. parahaemoliticus, E. tarda and $V$. salmonicida) bacteria. This article reports structure elucidation of agelasines B and D and antibacterial of the crude extract of Agelas sp. towards fish pathogenic and ESKAPE bacteria.

\section{MATERIALS AND METHODS}

\section{Sample collection}

With the help of self-contained underwater breathing apparatus (SCUBA), the specimen was collected on July 5, 2017 by hand from Enepahembang, East Tahuna, Sangihe Islands in North Sulawesi Province, Indonesia at a depth of $\sim 6 \mathrm{~m}$ and geographical position of $3^{\circ} 36^{\prime} 00.7^{\prime \prime} \mathrm{N}$, $125^{\circ} 29^{\prime} 44.5^{\prime \prime} \mathrm{E}$ (Figure 1). Soon after morphological description and underwater photograph, the specimen was cut ( $<10 \%$ of the total mass), individually kept in a zipped plastic bag and brought to the laboratory in Nusa Utara Polytechnic, Tahuna, North Sulawesi, Indonesia where the specimen was stored at a $-16^{\circ} \mathrm{C}$ freezer until used.

\section{Test bacteria}

The isolates were obtained from the American Type Culture Collection including Aeromonas hydrophila (ATCC 35654) Vibrio parahaemolyticus, Edwarsiella tarda (ATCC 33658), Staphylococcus aureus sub. (ATCC 25923), Acinetobacter baumannii (ATCC 19606), and Klebsiella pneumoniae (ATTC BAA-1705).

\section{Antibacterial evaluation}

Nutrient agar and 1\% marine broth were prepared for Acinetobacter baumannii and Klebsiella pneumoniae and nutrient agar $+1 \%$ Brain Heart Infusion (BHI) Broth was prepared for Staphylococcus aureus. The bacteria were streak on media and were left for 2 hours before antibacterial test. For the test, disc diffusion method was adopted. Blank disk Whatman papers $(6 \mathrm{~mm})$ were impregnated with $20 \mu \mathrm{L}$ of extract and/or antibiotic, positioned on the agar plate after dry and allowed to dry in an incubator at $37^{\circ} \mathrm{C}$ for $12-24$ hours before the measurement of inhibition zone around the paper disk.

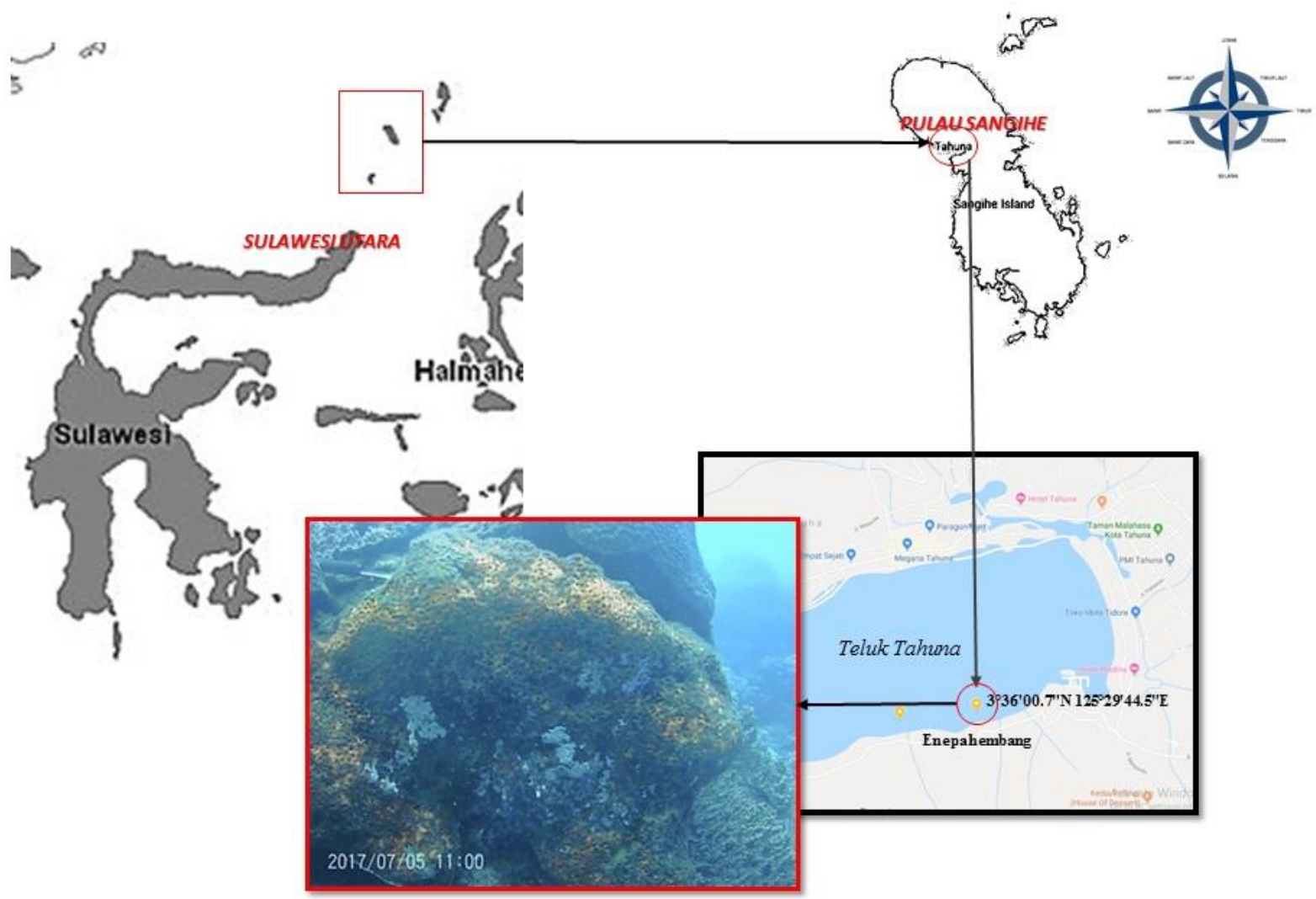

Figure 1. Map of sampling location in Enepahembang Sangihe Islands, North Sulawesi, Indonesia and the specimen with the image in the lower right-hand corner showing the location site (accessed from Google map in October 2019) and the front image showing underwater photograph of the sponge Agelas sp. 
Table 1. Comparison of NMR data of agelasine B (DMSO) and Compound $1\left(\mathrm{CD}_{3} \mathrm{OD}\right)$

\begin{tabular}{|c|c|c|c|c|}
\hline \multirow{2}{*}{$\frac{\#}{1}$} & \multicolumn{2}{|c|}{$\begin{array}{l}\delta_{\mathrm{H}}(\text { mult., } J(\mathrm{~Hz}))(+)- \\
\text { Agelasine B (DMSO) }\end{array}$} & \multicolumn{2}{|c|}{$\begin{array}{l}\delta_{\mathrm{H}}(\text { mult., } J(\mathrm{~Hz})) \\
\text { comp. } 1\left(\mathrm{CD}_{3} \mathrm{OD}\right)\end{array}$} \\
\hline & $1.54, \mathrm{~m}$ & $17.8, \mathrm{CH}_{2}$ & $1.53, \mathrm{~m}$ & $18.2, \mathrm{CH}_{2}$ \\
\hline 2 & $1.98, \mathrm{~m}$ & $26.3, \mathrm{CH}_{2}$ & $2.04, \mathrm{~m}$ & $29.1, \mathrm{CH}_{2}$ \\
\hline 3 & $5.13, \mathrm{~s}$ & $120.2, \mathrm{CH}$ & $5.21, \mathrm{~s}$ & $120.3, \mathrm{CH}$ \\
\hline 4 & & 143.6, C & & 145.1, C \\
\hline 5 & & $37.6, \mathrm{C}$ & & $38.5, \mathrm{C}$ \\
\hline $6 a$ & $\begin{array}{c}1.65, \mathrm{dt} \\
(13.2,3.0)\end{array}$ & $36.2, \mathrm{CH}_{2}$ & $1.60 \mathrm{~m}$ & $36.3, \mathrm{CH}_{2}$ \\
\hline $6 \mathrm{~b}$ & $1.10, \mathrm{~m}$ & & & \\
\hline $7 \mathrm{a}$ & $1.46, \mathrm{~m}$ & $27.0, \mathrm{CH}_{2}$ & $2.01 \mathrm{~m}$ & 28.6, $\mathrm{CH}_{2}$ \\
\hline $7 b$ & $1.38, \mathrm{~m}$ & & $1.48 \mathrm{~m}$ & \\
\hline 8 & $1.42, \mathrm{~m}$ & $35.7, \mathrm{CH}$ & $1.50 \mathrm{~m}$ & $36.1, \mathrm{CH}$ \\
\hline 9 & & $38.2, \mathrm{C}$ & & $38.2, \mathrm{C}$ \\
\hline 10 & 1.29 & $45.9, \mathrm{CH}$ & $1.50 \mathrm{~m}$ & $48.1, \mathrm{CH}$ \\
\hline $11 \mathrm{a}$ & 1.47 & $35.8, \mathrm{CH}_{2}$ & $1.60 \mathrm{~m}$ & $36.2, \mathrm{CH}_{2}$ \\
\hline $11 b$ & 1.35 & & & \\
\hline $12 \mathrm{a}$ & 1.97 & $32.5, \mathrm{CH}_{2}$ & $2.15 \mathrm{~m}$ & $34.1 \mathrm{CH}_{2}$ \\
\hline $12 b$ & 1.84 & & $2.05 \mathrm{~m}$ & \\
\hline 13 & & 146.2, C & & $150.0, \mathrm{C}$ \\
\hline 14 & $5.45, \mathrm{t}(6.0)$ & $114.9, \mathrm{CH}$ & $\begin{array}{l}5.57, \mathrm{t} \\
(6.0)\end{array}$ & $115.4, \mathrm{CH}$ \\
\hline 15 & $5.16, \mathrm{~d}(6.0)$ & $47.0, \mathrm{CH}_{2}$ & 5.19 br s & 47.9, $\mathrm{CH}_{2}$ \\
\hline 16 & $1.79, \mathrm{~s}$ & $16.7, \mathrm{CH}_{3}$ & $1.75, \mathrm{~s}$ & $16.7, \mathrm{CH}_{3}$ \\
\hline 17 & $0.78, \mathrm{~s}$ & $15.8, \mathrm{CH}_{3}$ & $\begin{array}{c}0.87, \mathrm{~d} \\
(1.8)\end{array}$ & $14.5, \mathrm{CH}_{3}$ \\
\hline 18 & $1.54, \mathrm{~d}(1.2)$ & $17.7, \mathrm{CH}_{3}$ & $1.60(\mathrm{~s})$ & $18.7, \mathrm{CH}_{3}$ \\
\hline 19 & $0.95, \mathrm{~s}$ & $19.6, \mathrm{CH}_{3}$ & $1.06(\mathrm{~s})$ & $20.1, \mathrm{CH}_{3}$ \\
\hline 20 & $0.70, \mathrm{~s}$ & $18.1, \mathrm{CH}_{3}$ & $0.79(\mathrm{~s})$ & $18.3, \mathrm{CH}_{3}$ \\
\hline $2^{\prime}$ & $8.48, \mathrm{~s}$ & $155.4, \mathrm{CH}$ & $8.48(\mathrm{~s})$ & 157.1, CH \\
\hline $4^{\prime}$ & & $148.9, \mathrm{C}$ & & $150.1, \mathrm{C}$ \\
\hline $5^{\prime}$ & & 109.2, C & & 115.2, C \\
\hline $6^{\prime}$ & & $152.3, \mathrm{C}$ & & 152.0, C \\
\hline $8^{\prime}$ & & $140.9, \mathrm{CH}$ & & 142.0, C \\
\hline $9^{\prime}-\mathrm{CH}_{3}$ & $3.89, \mathrm{~s}$ & $31.4, \mathrm{CH}_{3}$ & $4.00(\mathrm{~s})$ & $31.1, \mathrm{CH}_{3}$ \\
\hline
\end{tabular}

\section{Sample preparation}

The sponge (500 $\mathrm{g}$ wet weight) was cut into small pieces and dried in the oven at $45^{\circ} \mathrm{C}$ for two days before used. The dried specimen (49.3 g dried weight) was soaked in $400 \mathrm{~mL} \mathrm{MeOH}$ overnight (2x), filtered and the combined supernatants were dried under a reduced pressure to yield $4.1 \mathrm{~g}$ crude extract. It was triturated with hexane, dichloromethane, methanol, and $\mathrm{H}_{2} \mathrm{O}$. The $\mathrm{MeOH}$ soluble was further subjected to separation with $\mathrm{SiO} 2$ gel column chromatography (gradient elution $90 \%$ Hexane to $100 \%$ DCM followed by $90 \% \mathrm{EtOH}$ to $100 \% \mathrm{MeOH}$ to give 10 fractions, two of which (fractions 6 and 7) were further fractionated by normal phase column chromatography (column F0220-205 g, 20 bar, gradient elution 0-100\% (Hexane, DCM, EtOAc) to $10 \% \mathrm{MeOH}$, flow rate 127 $\mathrm{mL} / \mathrm{min}$ for $40 \mathrm{~m}$ ) to afford 13 fractions.

Of these, the active sub-fraction 10 (141 mg) was further subjected to a repeated reversed-phase flash chromatography (the Interchim Puriflash 4125 chromatography system applied with a Puriflash $\mathrm{C}_{18}-\mathrm{HP} 30$ $\mathrm{mm}$ Flash column, gradient elution of $5 \% \mathrm{MeOH} / \mathrm{H}_{2} \mathrm{O}$ to $100 \% \mathrm{MeOH}$ over $1 \mathrm{~h}$ ) to give 10 fractions. Fraction 5
(25.0 mg) was further purified by HPLC (semi preparative column, EC Gravity $\mathrm{C}_{18}, 250 \times 10 \mathrm{~mm}$, gradient elution, $88 \% \mathrm{MeOH} / \mathrm{H}_{2} \mathrm{O}$ to $95 \% \mathrm{MeOH} / \mathrm{H}_{2} \mathrm{O}+0.01 \%$ TFA, flow rate $3.0 \mathrm{~mL} / \mathrm{min}$., over $30 \mathrm{~min}$.) to give 10 subfractions. Further purification of fraction 2 by HPLC (semi preparative column, EC Gravity $\mathrm{C}_{18}, 250$ x $10 \mathrm{~mm}$, gradient elution, $88 \% \mathrm{MeOH} / \mathrm{H}_{2} \mathrm{O}$ to $95 \% \mathrm{MeOH} / \mathrm{H}_{2} \mathrm{O}+$ $0.01 \%$ TFA, flow rate $3.0 \mathrm{~mL} / \mathrm{min}$., over $45 \mathrm{~min}$.) resulted in the isolation of agelasine B (1) (1.05 mg) and agelasine D (2) $(0.9 \mathrm{mg})$.

\section{Spectroscopic analysis}

NMR spectra were recorded in $\mathrm{MeOH}-d_{4}(\mathrm{ALDRICH}$, St. Louis, MO, USA) or chloroform-d with tetramethylsilane as an internal standard (ALDRICH, St. Louis, MO, USA), using a Bruker AV400 and $600 \mathrm{MHz}$ NMR spectrometer for 1D and 2D NMR data respectively (Brucker, Ettlingen, Germany). Mass spectra were recorded on a micrOTOF-Q mass spectrometer (Bruker, Billerica, MA, USA) with ESI-source coupled with a HPLC Dionex Ultimate 3000 (Thermo Scientific, Darmstadt, Germany) using an EC10/2 Nucleoshell C18 $2.7 \mu \mathrm{m}$ column (Macherey-Nagel, Düren, Germany). The column temperature was $25^{\circ} \mathrm{C}$. MS data were acquired over a range from 100 to $1000 \mathrm{~m} / \mathrm{z}$ in positive mode. Auto MS/MS fragmentation was achieved with rising collision energy $(35-50 \mathrm{keV}$ over a gradient from 500 to $2000 \mathrm{~m} / \mathrm{z})$ with a frequency of $4 \mathrm{~Hz}$ for all of the ions over a threshold of 100. The injection volume was $2 \mu \mathrm{l}$ with a concentration of $1 \mathrm{mg} / \mathrm{mL}$. Fractionation was performed on the Interchim Puriflash 4125 chromatography system and purification on a Shimadzu HPLC equipped with UV Vis and diode array.

\section{Identification of the sponge}

A small piece of the sponge specimen was added into $400 \mu \mathrm{L}$ lysis mix $(100 \mathrm{mM} \mathrm{NaCl}, 50 \mathrm{mM} 191$ Tris- $\mathrm{HCl} \mathrm{pH}$ 8.0, $10 \mu \mathrm{M}$ EDTA pH 8.0, 0.5\% SDS, $2 \mathrm{mg} / \mathrm{mL}$ Proteinase $\mathrm{K})$ and incubated at $56^{\circ} \mathrm{C}$ overnight (Vargas et al. 2012). Thereafter, genomic DNA was isolated using innuPREP Bacteria DNA Kit (Analytik Jena, Jena, Germany) and dialyzed using a $0.025 \mu \mathrm{m}$ nitrocellulose membrane (MerckTM MF-MilliporeTM, Ireland). Prior to PCR, the sponge genomic DNA was diluted 1:10. The following barcoding primers were used (Chombard et al. 1998): C2: 5'-GAAAAGAACTTTGRARAGAGAGT- 3' and D2: 5'TCCGTGTTTCAAGACGGG-3' to amplify the 28S rRNA fragment from the isolated sponge DNA. PCR program: initial denaturation at $95^{\circ} \mathrm{C}$ for 5 minutes; 34 cycles of $95^{\circ} \mathrm{C}$ for 45 seconds, $48^{\circ} \mathrm{C}$ for 45 seconds, $72^{\circ} \mathrm{C}$ for $30 \mathrm{sec}$ and final elongation at $72^{\circ} \mathrm{C}$ for $5 \mathrm{~min}$. In addition to that, a fragment of the mitochondrial cytochrome oxidase subunit 1 (CO1) was amplified using degenerated CO1 barcoding primers: dgLCO1490: 5'-GGT CAA CAA ATC ATA AAG AYA TYG G-3' and dgHCO2198: 5'-TAA ACT TCA GGG TGA CCA AAR AAY CA-3'. PCR program: initial denaturation at $95^{\circ} \mathrm{C}$ for 2 minutes; 37 cycles of $94^{\circ} \mathrm{C}$ for 40 seconds, $42^{\circ} \mathrm{C}$ for 40 seconds, $72^{\circ} \mathrm{C}$ for 1 minute and final elongation at $72^{\circ} \mathrm{C}$ for $5 \mathrm{~min}$. The amplified $28 \mathrm{~S}$ rRNA and CO1 fragments were sent to Microsynth Seqlab, 
Göttingen, Germany, for Sanger sequencing. Sequence reads were assembled in Clone Manager 9 and aligned by BLAST (NCBI) to determine the sponge identity.

\section{RESULTS AND DISCUSSION}

\section{Collection site and the sponge}

The orange, massive, rounded and encrusting sponge was consistently firmly spongy, resilient when wet and hardly compressible when dry. The exterior was reddishbrown to brick red and the interior had similar color but somewhat lighter when dry. The description matched the genus Agelas (Hoshino 1985) and was further supported by DNA barcoding analysis, allowing the assignment of the sponge as Agelas sp.

\section{Extraction and purification of Agelasines B and D}

The marine sponge (500 g, dry weight) was extracted with $\mathrm{MeOH}(2 \mathrm{x} 500 \mathrm{~mL})$. The residue was partitioned between Hexane, DCM, MeOH, and $\mathrm{H}_{2} \mathrm{O}$. One of the active fractions ( $\mathrm{MeOH}$ soluble) was passed through a chromatography column of silica gel 60 and eluted with hexane, DCM, EtOAc, and $\mathrm{MeOH}$ to obtain 13 fractions. Fraction 8 of this column was subjected to repeated separation with both normal and reversed-phase flash chromatography and followed by repeated purification by a reversed-phase high-performance liquid chromatography (HPLC) to give agelasine $\mathrm{B}$ (1) and agelasine D (2). The molecular formula of $\mathrm{C}_{26} \mathrm{H}_{40} \mathrm{~N}_{5}$ for both compounds was deduced from the HRESIMS. The ${ }^{1} \mathrm{H}$ NMR of 1 revealed the presence of two olefinic protons at $\delta_{\mathrm{H}} 5.21(\mathrm{H}-3)$ and $\delta_{\mathrm{H}}$ $5.57(\mathrm{H}-14)$, one doublet methyl at $0.87 \delta_{\mathrm{H}}(\mathrm{H}-17)$, two singlet methyls at $\delta_{\mathrm{H}} 1.06(\mathrm{H}-19)$ and at $\delta_{\mathrm{H}} 0.79(\mathrm{H}-20)$, one vinylic methyl at $\delta_{\mathrm{H}} 0.83(\mathrm{H}-18)$, four methylene protons at $\delta_{\mathrm{H}} 1.53(\mathrm{H}-1), \delta_{\mathrm{H}} 2.04(\mathrm{H}-2), \delta_{\mathrm{H}} 1.60(\mathrm{H}-6) \& \delta_{\mathrm{H}}$ $2.01(\mathrm{H}-7)$ and one methine proton at $\delta_{\mathrm{H}} 1.50(\mathrm{H}-8)$, indicative of a clerodane moiety in $\mathbf{1}$, which was further supported by the ${ }^{13} \mathrm{C}$ and HSQC data for C1 to C20 (Table 1). In addition, the $1 \mathrm{D}$ NMR data of 1 showed one olefinic proton at $\delta_{\mathrm{H}} 8.48\left(\mathrm{H}-2^{\prime}\right)$, one vinylic proton at $\delta_{\mathrm{H}} 1.75$ $\left(\mathrm{CH}_{3}-16\right)$ and one $N$-methyl at $4.0\left(\mathrm{CH}_{3}-9^{\prime}\right)$, three quaternary carbons at $\delta_{\mathrm{C}} 150.1\left(\mathrm{C}-4^{\prime}\right), 115.2\left(\mathrm{C}-5^{\prime}\right)$ and $152.0\left(\mathrm{C}-6^{\prime}\right)$, two sp ${ }^{2}$ carbons at $\delta_{\mathrm{C}} 157.1\left(\mathrm{CH}-2^{\prime}\right)$ and $142.0\left(\mathrm{CH}-8^{\prime}\right)$ as well as one $N$-methyl carbon at $\delta_{\mathrm{C}} 31.1$ $\left(\mathrm{CH}_{3}-9^{\prime}\right)$, suggestive of a purine moiety in $\mathbf{1}$ (blue, Figure 2 (A). E-configuration at C-13 was assigned based on the upfield chemical shift of $\mathrm{CH}_{3}-16\left(\delta_{\mathrm{C}} 16.7\right)$ (De Rosa et al. 1976). Thus, 1 is a terphenyl purine derivative, featuring a bicyclic diterpene connected to position 7 of a 9methyladenium chromophore, similar to that of agelasine A or B (Gordaliza 2010). However, the bridgehead methyl at $\mathrm{CH}_{3}-19$ of 1 had a high field resonance at $\delta_{\mathrm{C}} 19.5$, suggesting a transfused clerodane stereochemistry for $\mathbf{1}$ (pink, Figure 2 (A), matching that of agelasine B (Nakamura et al. 1984). This was further supported by COSY and HMBC correlations, establishing connections for clerodane diterpene, $N$-methyladenium and the two functionalities (Figure 2, (A)- (C)). Therefore, compound 1 was assigned as agelasine $\mathrm{B}$.

Comparison of the ${ }^{1} \mathrm{H}$ NMR spectra between agelasines B (1) and D (2) showed a striking similarity (Figure 3). The only difference lied in the disappearance of a vinylic proton at $\delta_{\mathrm{H}} 5.21(\mathrm{H}-3)$ and a methine proton at $\delta_{\mathrm{H}} 1.50(\mathrm{H}-8)$ from the ${ }^{1} \mathrm{H}$ NMR spectrum of 2 in exchange of two exoolefins at $\delta_{\mathrm{H}} 4.56(\mathrm{H}-17 \mathrm{a})$ and at $\delta_{\mathrm{H}} 4.59(\mathrm{H}-17 \mathrm{~b})$, methine proton at $1.52(\mathrm{H}-9)$ and methine proton and the shift of a bridgehead proton from $\delta_{\mathrm{H}} 1.06(\mathrm{H}-19) \delta_{\mathrm{H}}$ to $\delta_{\mathrm{H}} 0.97(\mathrm{H}-$ 20) in $\mathbf{2}$, indicative of a rearranged labdane in $\mathbf{2}$ as shown. The ${ }^{1} \mathrm{H}$ NMR data of $\mathbf{2}$ matched those of agelasine D (Nakamura et al. 1984) and ageloxime D (Yang et al. 2012). In particular, the comparison of the ${ }^{1} \mathrm{H}$ NMR spectrum of $\mathbf{2}$ with that of ageloxime showed an exact match (Yang et al. 2012 and its supporting information). Therefore, compound $\mathbf{2}$ was tentatively assigned as having similar stereochemistry to agelasine D (Nakamura et al. 1984) and ageloxine D (Yang et al. 2012) but the same structure with that of agelasine D (Nakamura et al. 1984).

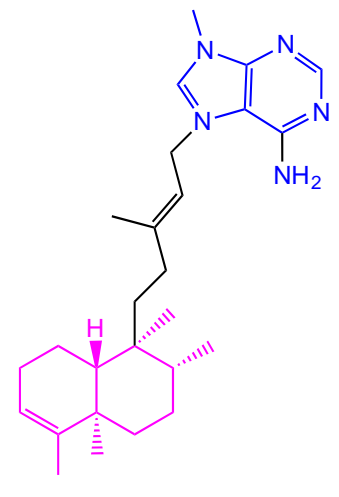

A

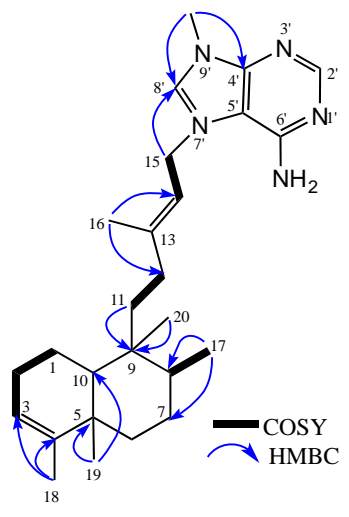

B

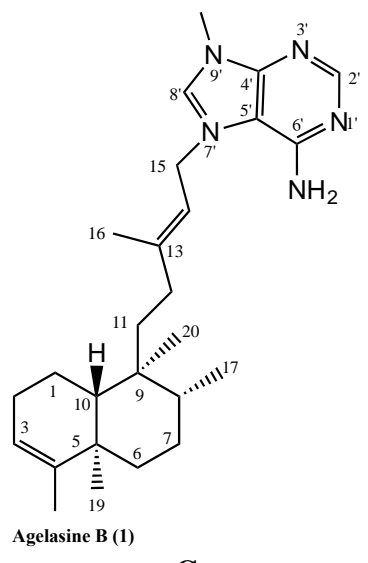

C

Figure 2. Clerodane and methyladenium functionalities (A), selected COSY and HMBC correlations (B) and agelasine B (1) (C) 


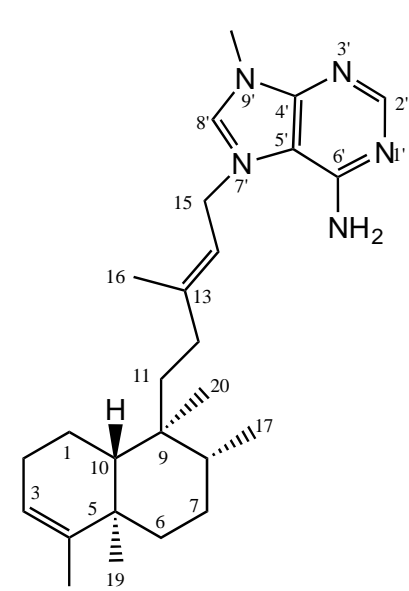

Agelasine B (1)

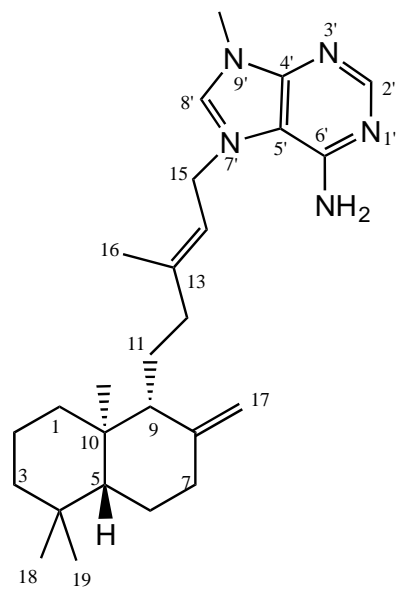

Agelasine D (2)
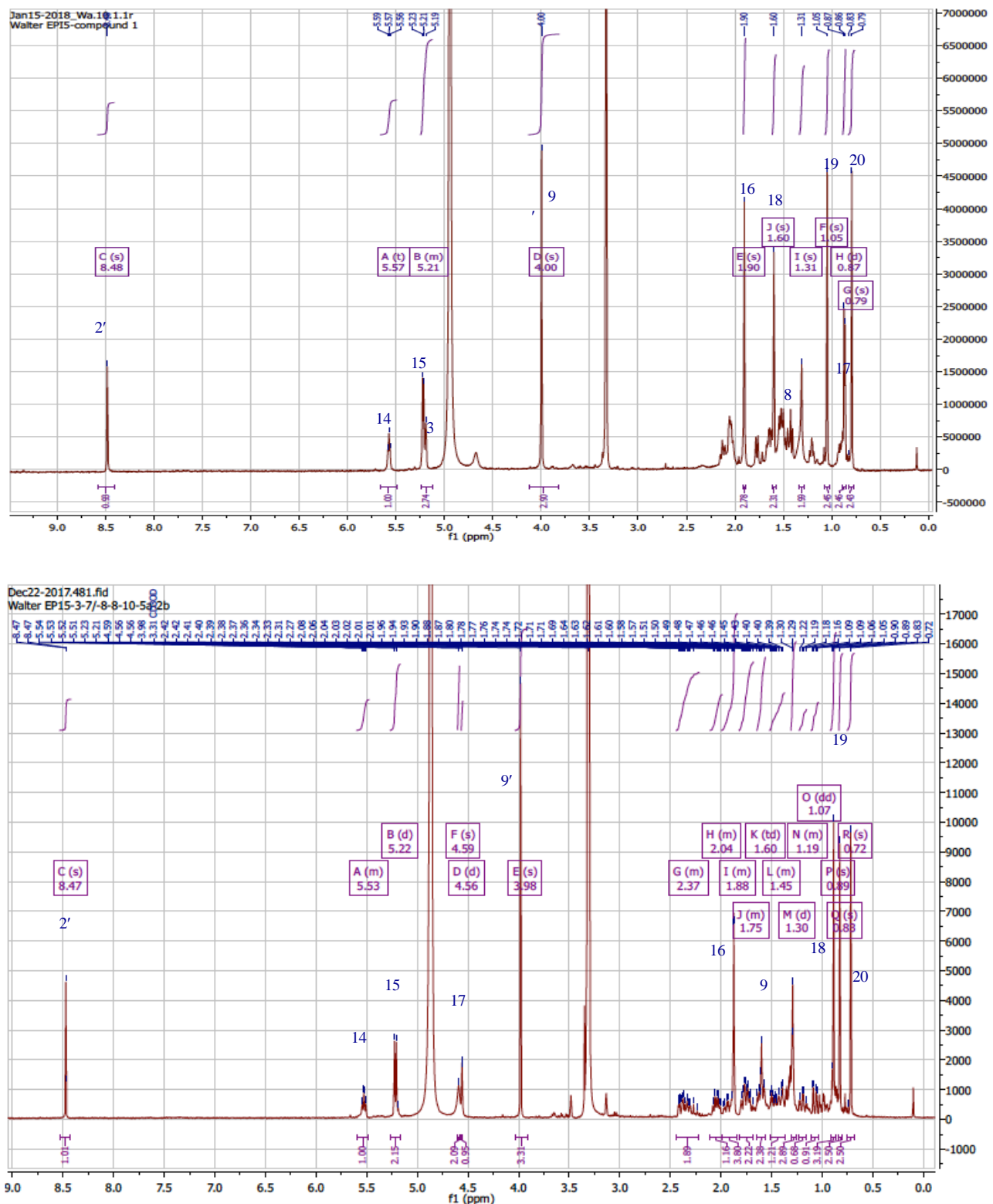

Figure 3. The ${ }^{1} \mathrm{H}$ NMR spectra of agelasine B (1) (above) and agelasine D (2) (below), showing the key protons for the two compounds

\section{Antimicrobial screening}

The standard disk diffusion method was used to screen antibacterial activity especially for the crude extract of Sangihe Agelas sp. with inhibition zone of the extract against the test bacteria shown in Table 2 .

The crude extract of Agelas sp. showed a broadspectrum antimicrobial activity. It exerted the strongest activity against the Gram-positive bacteria $S$. aureus with an inhibition zone of $25.3 \mathrm{~mm}$, strong activity against the Gram-negative E. tarda, A. salmonicida, A. hydrophila and A. baumannii with inhibition zones of $(22.4,21.2,20.5$ and 20.2) $\mathrm{mm}$ respectively and moderate activity against $K$. pneumoniae with an inhibition zone of $15.5 \mathrm{~mm}$. Except for $K$. pneumoniae, the antimicrobial activity of the extract against all test bacteria was relatively weaker (20.2-25.3 $\mathrm{mm}$ inhibition zone) than that of the commercial antibiotics (tetracycline) (21.3-27.0) $\mathrm{mm}$ inhibition zone. Unfortunately, the scarcity of the compounds-due to repeated purification of agelasine type compounds and their isomeric nature - prevented us from confirming the activity of agelasines B and D against the test bacteria. Nevertheless, previous studies on antimicrobial activity of agelasines B and D showed that both compounds had potent antimicrobial activity against $S$. aureus (Vik et al. 2006; Hong et al. 2017). Also, agelasine D had a strong and broad-spectrum antimicrobial activity against Mycobacterium tuberculosis and both aerobic and anaerobic Gram-positive and negative bacteria (Hong et al. 2017). Taken together, they suggest that the antimicrobial activity of the Sangihe's Agelas sp. might be due to the presence of agelasines $B$ and $D$. 


\section{Discussion}

The result showed that Gram-positive bacteria were more sensitive (inhibition zone $>25 \mathrm{~mm}$ ) against the extract than the Gram-negative ones (inhibition zone $<22.5 \mathrm{~mm}$ ) at least in terms of inhibition zone. This agrees with the previous reports that claimed the sensitivity of the Grampositive over the Gram-negative bacteria (Tadesse et al., 2008). When the researchers screened extracts of Norwegian sponges and ascidians for antibacterial activity, they discovered $29 \%$ of the extracts were active against Gram-positive bacteria but only $15 \%$ against Gramnegative bacteria. The same results were also found in various screening efforts on the Caribbean sponge with the Gram-positive being more sensitive towards extracts than their Gram-positive counterparts (McCaffrey and Andean 1985; Amade et al. 1987). This is even true for medical plant extracts. Koohsari et al. (2015), reported the susceptibility of Gram-positive bacteria over the Gramnegative bacteria with $S$. aureus being one the most susceptible Gram-positive bacteria while Escherichia coli and Klebsiella pneumoniae as the most resistant Gramnegative bacteria.

However, the antimicrobial activity of the extract against a range of Gram-negative bacteria is also encouraging. For one thing, the discovery of antibiotics against Gram-negative bacteria is always challenging. GlaxoSmithKline, for example, reported that the company did not discover any antibiotic hits even after screening 50,000 synthetic compounds against $E$. coli (Richter et al. 2017). Low permeability of Gram-negative bacteria's outer membrane is generally accepted as the major reason for the resistance of Gram-negative bacteria against many commercial antibiotics (Fair and Tor 2014). Hence, the ability of the Agelas's extract to exert antibacterial activity against various Gram-negative bacteria suggests that either agelasine $\mathrm{B}$ or $\mathrm{D}$ or the combination of these compounds have the capacity to penetrate the Gram-negative bacteria's outer membrane.

Table 2. Antibacterial activity of crude extract against various bacteria determined by the standard disk diffusion method.

\begin{tabular}{|c|c|c|c|c|}
\hline \multirow[b]{3}{*}{ Bacterial strains } & \multicolumn{4}{|c|}{ Zone of inhibition (mm) } \\
\hline & \multicolumn{3}{|c|}{$\begin{array}{c}\text { Metabolites of } \\
\text { Agelas sp. } \\
\end{array}$} & \multirow{2}{*}{ 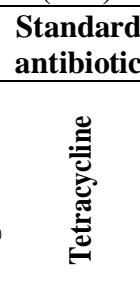 } \\
\hline & 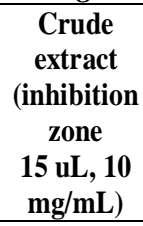 & 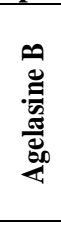 & & \\
\hline Staphylococcus aureus ATCC 25923 & $25.3 \mathrm{~mm}$ & $\mathrm{a}$ & & $27.0 \mathrm{~mm}$ \\
\hline Acinetobacter baumannii ATCC 19606 & $20.2 \mathrm{~mm}$ & $\mathrm{a}$ & $\mathrm{a}$ & $21.3 \mathrm{~mm}$ \\
\hline Aeromonas hydrophila ATCC 35654 & $20.5 \mathrm{~mm}$ & $\mathrm{a}$ & $\mathrm{a}$ & $22.3 \mathrm{~mm}$ \\
\hline Aeromonas salmonicida & $21.2 \mathrm{~mm}$ & $\mathrm{a}$ & $\mathrm{a}$ & $21.7 \mathrm{~mm}$ \\
\hline Edwardsiella tarda ATCC 33658 & $22.4 \mathrm{~mm}$ & $\mathrm{a}$ & a & $26.7 \mathrm{~mm}$ \\
\hline $\begin{array}{l}\text { Klebsiella pneumoniae ATCC BAA- } \\
1705\end{array}$ & $15.5 \mathrm{~mm}$ & a & a & $14.0 \mathrm{~mm}$ \\
\hline
\end{tabular}

Note: a: No data obtained
Curiously, agelasines B and D contained a primary amine and a similar functional group, secondary amine, was reported to have a significant impact on antimicrobial activity of cholic acid derivatives ( $\mathrm{Li}$ et al. 1999). Many other amine-containing compounds possessed bioactivity against Gram-negative bacteria. For another, it has been known that the most serious infection threat of Gramnegative bacteria might come from Klebsiella pneumoniae and Acinetobacter (Ventola 2015) and other Gram-negative ESKAPE bacteria due to their dual membrane envelopes that prevent many antibiotics from accessing their targets (Smith et al. 2018). This also means that the current result might be of interest for antibiotic drug lead discovery although such notion remains to be studied before any conclusion can be drawn.

Moreover, the result may also have relevance to the current emerging ideas of drug modification, redirection and repurposing (Richter et al. 2017; Canturri et al. 2019; Jang et al. 2019). Although antimicrobial drug repurposing is not a new concept, it is gaining momentum due to the alarming increase of antibiotic-resistant bacteria and the scarcity of available new antibiotics particularly for treating Gram-negative bacteria (Canturri et al. 2019). Through this approach, several drugs that were earlier not meant for antibiotics such as anthelmintic, anticancer, antiinflammatory, immunomodulators, antipsychotic and antidepressant drugs have been repurposed, leading to the discovery of several new antibiotics including aurofonin, chlorocyclizine, and pentamidine (Fahra and Brown 2019). Over the years, agelasines are known for their broad range of bioactivities particularly as anticancer and antimicrobial agents with agelasine D proven to bind to BCG3185c protein as its main target in exerting its antimycobacterial activity against the Gram-negative bacteria Mycobacterium tuberculosis (Arai et al. 2014). Along with these facts, the present result indicates the possibility of agelasines B and/or D to be an antibiotic drug lead for treating Gramnegative bacteria.

Furthermore, the present result is presumably relevant for the current concept of drug redirection (Jang et al. 2019). With this approach, any known drugs (e.g. anticancer or other types of drugs) provided that they have antibacterial activity were redesigned or synthesized and later evaluated as antibiotics against the gram-negative bacteria (Jang et al. 2019). Early this year, Jang et al. (2019) reported that they obtained potent new antibiotic leads by slightly modifying the structure of the anticancer drug YM155 and its analogs. In fact, introduction of a methyl group on the purine of agelasine significantly improved the activity of agelasine type compounds against several Gram-positive bacteria, protozoans and cancer cell lines (Rogen et al. 2011). Modifications of the length, geometry, and purine moieties have also proven to improve the bioactivity of agelasine type compounds (Bakkestuen et al. 2005). To date, however, this effort is limited to targeting Gram-positive bacteria and Mycobacterium tuberculosis with the same effort on other Gram-negative bacteria is yet to be seen.

Another relevant concept with the present result is the design of molecules by focusing on the permeation and 
accumulation of molecules into the Gram-negative bacteria's cells. Richter et al. (2017) reported that one of the keys for molecules to exert antibacterial activity against Gram-negative bacteria is to contain amine, have globular and rigid structure. The authors went on saying that although amine was not the only component needed for the efficacy of antibiotics against Gram-negative bacteria, this functionality permits molecules with this moiety to permeate through porin and accumulate in the bacteria cells, therefore exerting antibacterial activity against Gramnegative bacteria. Curiously, cholic acids containing three amine groups and cycloamide discovered through drug repurposing were reported as potent antibacterial that sensitized the Gram-negative bacteria (Richter et al. 2017). Thus, it is interesting to see whether or not the primary amine in purine functionality of agelasines B and D would play a key role in the current observed antimicrobial activity on various Gram-negative bacteria and whether or not the modification of this functionality will result in antibiotic drug leads.

The current result may also find relevancy in the idea of combining known compounds with one or two antibiotics to improve the activity of both new or the last resource antibiotics (Bassetti and Righi 2015). This approach has resulted in the discovery of promising antibiotic drug leads that are currently in phases 2 and 3 of the clinical trials (Bassetti and Righi 2015). A typical example is a combination of clavulanic acid and various $\beta$-lactam antibiotics, which restored the function of many $\beta$-lactamcontaining antibiotics (Fahra and Brown 2019). Due to their broad range bioactivities and the present result, combination of agelasine $\mathrm{B}$ or $\mathrm{D}$ with commercial antibiotics would be an interesting alternative to discover antimicrobial drug leads for Gram-negative bacteria.

Therefore, this report provides evidence of antibacterial activity of extract of Agelas sp. from which agelasines B and $\mathrm{D}$ were isolated. In addition to providing isolation, purification and structure elucidation of agelasines B and $\mathrm{D}$, this article describes the activity of the crude extract of Agelas sp. against a series of Gram-negative bacteria, which to our best knowledge represents the first report on the antimicrobial activity of agelasine type compounds against the Gram-negative fish pathogenic and ESKAPE bacteria.

\section{ACKNOWLEDGEMENTS}

The authors thank the Indonesian Ministry of Research Technology and Higher Education for the Basich Research Grant Scheme (No. 01/PL30/P3M/P-DSR/2019), Prof Till F. Schäberle (Justus-Liebig-University Giessen) for allowing one of the authors (WB) to use his laboratory and research facilities, Heike Hausmann (Justus-LiebigUniversity Giessen) for measuring the capillary NMR spectra, John Heep (Justus-Liebig-University Giessen) for measuring the LC-HRESIMS data, and Herjumes Atjin (Ucil) (Nusa Utara State Polytechnic) for collecting the sample.

\section{REFERENCES}

Amade P, Charroin C, Baby C, Vacelet J. 1987. Antimicrobial activities of marine sponges from Mediterranean Sea. Mar Biol 94 (2): 271-275 DOI: 10.1007/BF00392940

Appenzeller J, Mihci G, Martin MT, Gallard JF, Menou JL, BouryEsnault N, Zaparucha A. 2008. Agelasines J, K, and L from the Solomon Islands marine sponge Agelas cf. mauritiana. J Nat Prod 71 (8): 1451-1454.

Arai M, Yamano Y, Setiawan A, Kobayashi M. 2014. Identification of the target protein of Agelasine D, a marine sponge diterpene alkaloid, as an anti-dormant mycobacterial substance. Chemibiochem 15 (1): 117 123. DOI: $10.1002 /$ cbic. 201300470 .

Azhari D, Makiseke AM, Tomasoa AM, Lumiu G, Balansa W. 2018. Aktivitas antibakteri ekstrak kasar spons Agelas clathrodes terhadap bakteri patogenik ikan Vibrio parahaemolyticus. Jurnal Tindalung 4 (2): 53-56. [Indonesian]

Bakkestuen AK, Gundersen LL, Petersen D, Utenova BT, Vik A. 2005. Synthesis and antimycobacterial activity of agelasine E and analogs. Org Biomol Chem 3 (6): 1025-1033. DOI: 10.1039/b417471b

Balansa W, Azhari D, Babo D, Tomasoa AM. 2017. Aktivitas antibakteri ekstrak sponge perairan enepahembang terhadap bakteri patogenik ikan Aeromonas hydrophila. Jurnal Tindalung 3 (1): 1-7. DOI: 10.5281/jit.v3i1.93. [Indonesian]

Balansa W, Mettal U, Wuisan ZG, Plubrukarn A, Frans GI, LiuY, SchaeberleTF. 2019. A new sesquiterpenoid aminoquinone from and Indonesian marine sponge. Mar Drugs 17 (3): 158. DOI: 10.3390/md17030158

Bassetti M, Righi E. 2015. New antibiotics and antimicrobial combination therapy for the treatment of gram-negative bacterial infections. Curr Opin Crit Care 21 (5): 402-411. DOI: 10.1097/MCC.0000000000000235.

Capon RJ, Faulkner DJ. 1994. Antimicrobial metabolites from a Pacific sponge, Agelas sp. J Am Chem Soc 106 (6): 1819-1822. DOI: 10.1021/ja00318a045.

Canturri AM, Agaba RA, Smani Y. 2019. Drug repurposing for the treatment of bacterial and fungal infections. Front Microbiol10, 1-12. DOI: 10.3389/fmicb.2019.00041.

Chombard C, Boury-Esnault N, Tillier S. 1998. Reassessment of homology of morphological characters in tetractinellid sponges based on molecular data. Syst Biol 47 (3): 351-366.

De Rosa S, Minale L, Riccio R, Sodano G. 1976. The absolute configuration of avarol, a rearranged sesquiterpenoid hydroquinone from a marine sponge. J Chem Soc Perkin Trans 1 (13): 1408-1414.

Fahra MA, Brown ED. 2019. Drug repurposing for antimicrobial discovery. Nat Microbiol 4: 565-577. DOI: 10.1038/s41564-019-035.

Fair RJ, Tor Y. 2014. Antibiotics and bacterial resistance in the $21^{\text {st }}$ century. Perspect Med Chem 6: 25-64. DOI: 10.4137/PMC.S14459

Founou RC, Founou LL, Essack SY. 2017. Clinical and economic impact of antibiotic resistance in developing countries: a systematic review and meta-analysis. PLoS ONE 12: 12. DOI: 10.1371/journal.pone. 0189621 .

Gordaliza M. 2010. Terpenyl-Purines from the Sea. Cytotoxic terpene quinones from marine sponge. Mar Drugs 8: 2849-2870.

Hong LL, Sun JB, Yang F, Liu M, Tang J, Sun F, Lin HW. 2017. New diterpene alkaloids from the marine sponge Agelas mauritiana. RSC Adv 7 (39): 23970-23976.

Hoshino T. 1985. Description of two new species in the genus Agelas (Demospongia) from Zamami Island, the Ryukyus Japan. Proc Jpn Soc Syst Zool 30: 1-10, pls I-II.

Jang HJ, Chung YI, Lim C, Chung S, Kim B, Kim ES, Kim SH, Cho YH. 2019. Redirecting an anticancer to antibacterial hit against methicillin-resistant Staphylococcus aureus. Front Microbiol 10: 350 DOI: $10.3389 /$ fmicb.2019.00350.

Koohsari H, Ghaemi EA, Sheshpoli MS, Jahedi M, Zahiri M. 2015. The investigation of antibacterial activity of selected native plants from North Iran. J Med Life 38-42.

Li C, Lewis MR, Gilbert AB, Noel MD, Schoville DH, Aliman GW, Savage PB. 1999. Antimicrobial activities of amine and guanidine functionalized cholic acid derivatives. Antimicrob Agents Chemother 43 (6): $1347-1349$

McCaffrey EJ, Andean R. 1985. Antimicrobial activity of tropical and sub-tropical sponges. Mar Biol 89 (1): $1-8$ DOI: 10.1007/BF00392871 
Miller RA, Harbottle H. 2018. Antimicrobial drug resistance in fish pathogens. Microbiol Spectrum 6: 1. DOI 10.1128/microbiolspec.ARBA-0017-2017.

Nakamura H, Wu H, Ohizumi Y, Hirata Y. 1984. Agelasine-A, -B, -C and -D, novel, bicyclic diterpenoids with a 9-methyladeninium unit possessing inhibitory effects on na, K-ATPase from the Okinawa sea, sponge Agelas sp. Tetrahedron Lett 25 (28): 2989-2992. DOI: 10.1016/S0040-4039 (01)81345-9

Navidinia M. 2016. The clinical importance of emerging ESKAPE pathogens in nosocomial infections. J Paramed Sci 7: 2008-4978. DOI: $10.22037 /$ jps.v7i3.12584.

Richter MF, Drown BS, Riley AP, Garcia A, Shirai T, Svec RL, Hergenbrother SP. 2017. Predictive compound accumulation rules yield a broad-spectrum antibiotic. Nature 545 (7654):299-304. DOI: 10.1038 /nature22308

Rogen H, Charnock C, Burman R, Feith J, Larson R, Lotte L, Gundersen II. 2011. Antimicrobial and antineoplastic activities of agelasine analogs modified in the purine 2-position. Arch Pharm 344 (1): 50-55 DOI: 10.1002/ardp.201000148

Smith PA, Koehler MFT, Girgis HS, Yan D, Chen Y, Chen Y, Crawford JJ, Durk MR, Higuchi RI, Kang J, Murray J, Paraselli P, Park M, Phung W, Quinn JG, Roberts TC, Rouge L, Schwarz JB, Skippington E, Wai J, Xu M, Yu Z, Zhang H, Tan MW, Heise CE. 2018 Optimized arylomycins are a new class of gram-negative antibiotics. Nature 561: 189-194. DOI: 10.1038/s41586-018-0483-6

Vargas S, Schuster A, Sacher K, Buettner G, Schaetzle S, Laeuchli B, Woerheide G. 2012. Barcoding sponges: an overview based on comprehensive sampling. PloS One 7 (7).

Tadesse M, Gulliksen B, Strom MB, Styrvold OB, Haug T. 2008 Screening for antibacterial and antifungal activities in marine benthic invertebrates from northern Norway. J Invertebr Pathol 99 (3):286-93. DOI: $10.1016 /$ j.jip.2008.06.009

Tacconelli E, Carrara E, Savoldi A, Harbarth S, Mendelson M, Monnet DL. 2018. Discovery, research, and development of new antibiotics: the WHO priority list of antibiotic-resistant bacteria and tuberculosis. Lancet Infect Dis 18: 318-327. DOI: 10.1016/S1473-3099 (17)307533

Tommasi R, Brown DG, Walkup GK, Manchester JI, Miller AA. 2015. Eskapeing the labyrinth of antibacterial discovery. Nat Rev Drug Dis 14 (8): 529-542. DOI: $10.1038 / \mathrm{nrd} 4572$.

Ventola CL. 2015. The antibiotic resistance crisis: part 1: causes and threats. P\&T 40 (4): 277-283.

Vik A, Hedner E, Charnock C, Samuelsen $\emptyset$, Larsson R, Gundersen LL, Bohlin L. 2006. (+)-Agelasine D: improved synthesis and evaluation of antibacterial and cytotoxic activities. J Nat Prod 69 (3): 381-386.

Vik A, Prosyenak A, Vermeersch M, Cos P, Maes L, Gundersen LL. 2009. Screening of Agelasine D and analogs for inhibitory activity against pathogenic protozoa; identification of hits for visceral leishmaniasis and Chagas disease. Molecules 14 (1): 279-88. DOI: 10.3390/molecules14010279.

World Health Organisation. 2017. WHO publishes list of bacteria for which new antibiotics are urgently needed. https://www.who.int/news-room/detail/27-02-2017-who-publisheslist-of-bacteria-for-which-new-antibiotics-are-urgently-needed [October 2019].

Yang F, Hamann MT, Zou Y, Zhang MY, Gong XB, Xiao JR, Chen WS, Lin HW. 2012. Antimicrobial metabolites from the Paracel Islands sponge Agelas mauritiana. J Nat Prod 75 (4): 774-778. DOI: $10.1021 / \mathrm{np} 2009016$ 